\section{Evaluation of a Phytotoxin(s) from Pseudomonas syringae for Weed Control in Cranberries}

\author{
Michael A. Norman ${ }^{1}$ and Kim D. Patten ${ }^{2}$ \\ Washington State University, Long Beach Research and Extension Unit, Route \\ 1, Box 570, Long Beach, WA 98631-9611
}

\section{Sarangamat Gurusiddaiah ${ }^{3}$ \\ Washington State University, Bioanalytical Research Center, Pullman, WA 99164-4235}

Additional index words. Vaccinium macrocarpon, biological control agent, integrated pest management

\begin{abstract}
Three indicator species [rye (Secale cereale L.), radish (Raphanus sativus L.), and alfalfa (Medicago sativa L.)] and nonrooted cuttings of 'Stevens' cranberry (Vaccinium macrocarpon Ait.) vines were grown in pots to establish the dose response levels for a sandapplied phytotoxin(s) from a crude extract of Pseudomonas syringae (strain 3366) culture. At 114 ppm [milligrams phytotoxin(s)/kilograms sand], the material was noninhibitory, whereas $1140 \mathrm{ppm}$ reduced root and shoot growth significantly in all four species. In subsequent experiments, a 10-ppm dose controlled corn spurry (Spergula arvensis L.) and fireweed (Epilobium angustifolium L.) seedlings, while $103 \mathrm{ppm}$ reduced root or shoot growth of cuttings of the perennial weeds birdsfoot trefoil (Lotus corniculatus L.) and silverleaf (Potentilla pacifica Howell). Root and shoot growth of partially rooted 'McFarlin' cranberry vines was reduced at 103 and $563 \mathrm{ppm}$, respectively. The phytotoxin(s) could potentially control germinating annual weeds in newly established 'Stevens' cranberry bogs.
\end{abstract}

Competition from weeds reduces cranberry yields significantly (Swanton et al., 1993). Annual weeds (e.g., corn spurry) reduce vine establishment in new bogs and yields in bearing bogs (Eck, 1990). Perennial weeds (e.g., silverleaf, birdsfoot trefoil, and fireweed) reduce cranberry yields an average of $25 \%$ (Swanton et al., 1993). The use of biological organisms, such as entomopathogenic nematodes, to control other cranberry pests, such as black vine weevil (Otiorhynchus ovatus F.), has become common (Shanks and AgudeloSilva, 1990). An environmentally benign means of controlling weeds would be desirable in cranberry bogs (wetland environment).

Soil-borne rhizobacterial pseudomonads (collective term for Pseudomonas species) were identified initially as the cause of stand reductions in continuous no-till winter wheat (Triticum aestivum L.) cropping systems

Received for publication 28 Dec. 1993. Accepted for publication 18 Aug. 1994. H/LA Paper no. 9326. Project no. 6090, College of Agriculture and Home Economics Research Center, Washington State Univ., Pullman. Ann C. Kennedy (U.S. Dept. of Agriculture-Agricultural Research Service, Washington State Univ., Pullman) supplied the culture of Pseudomonas syringae (strain 3366). Excellent technical assistance was provided by Christina Wolff. The use of trade names does not imply the exclusion of other products that may also be suitable. The cost of publishing this paper was defrayed in part by the payment of page charges. Under postal regulations, this paper therefore must be hereby marked advertisement solely to indicate this fact. ${ }^{1}$ Postdoctoral Research Associate.

${ }^{2}$ Associate Horticulturist.

${ }^{3}$ Associate Director, Bioanalytical Research Center.
(Elliott and Lynch, 1984). Reduced wheat seedling growth was due to the colonization of roots by pseudomonads (Bolton and Elliott, 1987; Elliott and Lynch, 1984) and subsequently attributed to a labile, constitutive phytotoxin(s) (Fredrickson and Elliott, 1985). Several selective pseudomonads severely reduced the root growth of the weed downy brome (Bromus tectorum L.) but not that of winter wheat (Cherrington and Elliott, 1987). This selective activity was identified as a potential source of biological weed control (Cherrington and Elliott, 1987). Of 1000 pseudomonads tested, $P$. fluorescens (strain D7) and $P$. syringae (strain 3366) consistently and selectively inhibited downy brome growth relative to winter wheat in growth chamber studies (Kennedy et al., 1991). A phytotoxin(s) in a crude extract from $P$. fluorescens (strain D7) inhibited root elongation of downy brome within $1.5 \mathrm{~h}$ (Tranel et al., 1993b). Cranberry, being a perennial, might tolerate the root elongation inhibitory effects of the phytotoxin(s) relative to germinating annual weed seedlings. The objective of this study was to evaluate the effectiveness of a phytotoxin(s) in a $P$. syringae (strain 3366) crude extract for weed control in cranberries.

\section{Materials and Methods}

Phytotoxin extraction and application. The phytotoxin was isolated from the aerobic fermentation culture of Pseudomonas syringae (strain 3366). We recognize that more than one phytotoxin may be involved; thus, we use the singular to represent either possibility.
Pseudomonas syringae was grown on a shaker at $250 \mathrm{rpm}$ at 24 to $26 \mathrm{C}$ for 48 to $72 \mathrm{~h}$. The culture medium contained $15 \mathrm{~g}$ proteose peptone, $1.5 \mathrm{~g}$ potassium sulfate, $1.5 \mathrm{~g}$ magnesium sulfate, and $12 \mathrm{ml}$ glycerol in 1 liter distilled water. The lipophilic fraction that previously had shown phytotoxic activity was isolated by mixing an equal volume of ethyl acetate with the fermentation broth overnight. The phytotoxin was then concentrated by reducing the ethyl acetate fraction to dryness and resuspending the residue in acetone. An aliquot of the acetone solution was dried and weighed to obtain a phytotoxin concentration (weight/ volume).

Four lots of air-dried sand ( $3.755 \mathrm{~kg}$ each) were passed through a 5-mm mesh screen and treated with $461 \mathrm{ml}$ each of an acetone solution containing $0,0.043,0.43$, and $4.3 \mathrm{~g}$ of phytotoxin. The $\mathrm{pH}$ (4.8) of the sand was typical of acidic bog soils (Eck, 1990). The acetone was then allowed to evaporate from the sand for $72 \mathrm{~h}$. The acetone treatment probably sterilized the sand to some degree and reduced the potential for biodegradation of the phytotoxin. The concentrations correspond, respectively, to $0,11.4,114$, and $1140 \mathrm{ppm}$ (milligrams phytotoxin/kilograms air-dried soil). In subsequent experiments, a similar protocol was used to obtain a range of $0,1,10$, 103,563 , and 1030 ppm phytotoxin.

Indicator species dose-response study. Initial experiments were conducted with cereal rye, radish, and alfalfa as indicator species to determine the effects of the phytotoxin on seed germination and seedling establishment. For the germination tests, $90 \mathrm{~g}$ of treated sand was placed in $100 \times 15$-mm petri plates and watered to field capacity. Fifteen seed were planted into each of six petri plates for every treatment, covered, and incubated for $40 \mathrm{~h}$ in darkness. The lids were removed from the plates and placed in a growth room. Seed were observed for radicle emergence after $32 \mathrm{~h}$.

For the rye, radish, and alfalfa seedling establishment study, $225 \mathrm{~g}$ of treated sand was placed in 195-cc pots with a paper towel lining the bottom. Seed were pregerminated on moist cheesecloth for $24 \mathrm{~h}$ in darkness. Five seed with an emerged radicle were then gently placed in each of two pots for every treatment. The sand for this experiment only was initially overwatered resulting in an extremely low seedling establishment for all treatments. The seed and seedlings were removed, and the sand was mixed thoroughly and allowed to dry. Seed were replanted in the same sand 3 weeks after phytotoxin application. We chose to continue with this experiment because our primary objective was to determine whether the phytotoxin could prevent seedling establishment. At 16 days after planting (DAP), surviving seedlings were scored individually as follows: 1) rye shoot height and weight, 2) radish shoot weight, and 3) the shoot area of alfalfa seedlings at 43 DAP.

Annual/perennial weed and cranberry dose-response studies. Runners from 'Stevens' cranberry were collected on 19 Apr. 1993 and pruned to obtain sections $(11 \mathrm{~cm}$ in length) that lacked roots and leaves. Cuttings were placed 
vertically to the bottom of 195 -cc pots containing sand treated with the phytotoxin. There were six pots per treatment and five cuttings per pot. The runners were harvested 38 DAP, and the total number of shoots, shoot weight, and the number of nodes that produced roots were determined.

For all subsequent experiments, $125 \mathrm{~g}$ of treated sand was placed in 120 -cc pots. Corn spurry and fireweed seed were pregerminated by soaking in water for $1 \mathrm{~min}$ in a beaker, then the water was poured off, the beakers capped with parafilm, and stored for $3 \mathrm{~h}$ in the dark. Sixteen seed each of corn spurry and fireweed were planted separately into four pots containing treated sand $(0,1,10,103,563$, and 1030 ppm). At 42 DAP, the shoot and root weights were determined for plants in each pot.

Cuttings were prepared on 13 July 1993 from established silverleaf and birdsfoot trefoil plants growing in a mature bog of 'McFarlin' cranberries. Each silverleaf cutting had the primary roots removed from a stolon segment (5 cm long) that had three leaves growing in a whorl. The roots were removed to obtain uniform cuttings. Birdsfoot trefoil cuttings were prepared by pruning the primary roots from a rhizome section $(3.2 \mathrm{~cm}$ long) that had one shoot with three trifoliate leaves. Newly formed shoot and root weights were determined for individual cuttings of silverleaf and birdsfoot trefoil at 43 DAP.

Established 'McFarlin' cranberry plants were obtained from an abandoned Sphagnum peat bog on 8 July 1993 and pruned so that each cutting had one upright stem with leaves attached to a 5.5-cm section of runner. The tip of each upright stem was removed to break apical dominance. Some adventitious roots were present along the runner. The total number of newly emerged 'McFarlin' shoots, shoot weight, and the number of nodes with roots were determined 67 DAP.

Pretreatment weights were obtained for silverleaf, birdsfoot trefoil, and 'McFarlin' cuttings. Two cuttings of each species were planted into each pot with rhizomes, stolons, or rooted runners just under the sand surface and incubated as described previously. There were six pots for each toxin level of 0,103 , 563, and $1030 \mathrm{ppm}$.

Culture conditions and statistics. For all experiments, pots were placed in mediumsized weigh boats and watered as necessary using subirrigation. Fertilizer $(33 \mathrm{ml} /$ pot of 3.0 g Miracle Gro/liter; Stern's Miracle-Gro Products, Port Washington, N.Y.) was added once weekly. Experiments were conducted at ambient room temperature (18 to $24 \mathrm{C}$ ) with a 16-h photoperiod $\left(75 \mu \mathrm{mol} \cdot \mathrm{m}^{-2} \cdot \mathrm{s}^{-1}\right.$ fluorescent lighting plus variable sunlight). A randomized complete-block design was used for all studies. Except for the indicator species doseresponse study, individual plants within pots were considered subsamples. Means were separated using Fisher's protected LSD.

\section{Results and Discussion}

Indicator species dose-response study. Phytotoxin at $0,11.4,114$, and $1140 \mathrm{ppm}$ did not significantly inhibit germination of rye, radish, and alfalfa seed 3 days after treatment (data not shown). However, radicle length was greatly reduced in all species at $1140 \mathrm{ppm}$. We used the narrow definition of germination, which includes the initial stages of biochemical reactivation and ends with the emergence of the radicle (Jann and Amen, 1977). The phytotoxin would have been considered a germination inhibitor if the broader definition had been used, which includes the development into an autotrophic seedling plant (U.S. Dept. of Agriculture, 1952). The inability of the phytotoxin to inhibit seed germination of these indicator species is consistent with a previous finding that the phytotoxin from $P$. fluorescens (strain D7) did not inhibit cell division in sensitive roots (Tranel et al., 1993a). The deleterious root-colonizing pseudomonads have been reported to reduce the germination of sugar beet (Beta vulgaris L.) (Suslow and
Schroth, 1982) and downy brome (Gealy et al., 1992; Gurusiddaiah et al., 1992) seed using the broad definition.

Shoot growth of rye, radish, and alfalfa seedlings was not reduced by the phytotoxin at 11.4 or $114 \mathrm{ppm}$ (Table 1); at $1140 \mathrm{ppm}$, however, it reduced shoot growth of all three indicator species. Although we chose not to present root growth inhibition data due to the low sample size $(n=2$, due to pooling of root mass from each pot), root growth was reduced in all three species at $1140 \mathrm{ppm}(P \leq 0.10$, data not shown). Based on these observations and previous reports, the phytotoxin may inhibit root development. The inhibitory effects on shoot growth could be secondary and occur because of an underdeveloped root system. These data also indicate that the phytotoxin had herbicidal activity even after being stored for 3 weeks in sand at near field capacity before the second planting.

Annual/perennial weed and cranberry dose-response studies. The phytotoxin did not reduce the number of shoots that developed in 'Stevens' cranberry vines by 38 DAP (Table 1). However, the average weight per shoot and the total number of nodes that produced adventitious roots were reduced at $1140 \mathrm{ppm}$. The 'Stevens' cranberry runners tolerated 114 ppm phytotoxin through 38 DAP.

Phytotoxin at $1 \mathrm{ppm}$ did not significantly reduce the establishment of corn spurry and fireweed seedlings by 42 DAP (Table 2 , see footnote). However, seedling establishment of both species was reduced $(P \leq 0.10)$ to $50 \%$ and $32 \%$ of the control, respectively, at 10 $\mathrm{ppm}$. The $103-\mathrm{ppm}$ rate provided nearly complete control of both weeds by 42 DAP (Table

Table 1. The effects of a phytotoxin from Pseudomonas syringae on the growth of germinated seedlings of three indicator species (rye, radish, and alfalfa) and 'Stevens' cranberry runners (weights, fresh basis).

\begin{tabular}{|c|c|c|c|c|c|c|c|}
\hline \multirow[b]{2}{*}{$\begin{array}{l}\text { Phytotoxin } \\
\text { (ppm) }\end{array}$} & \multicolumn{2}{|c|}{$\mathrm{Rye}^{\mathrm{z}}$} & \multirow{2}{*}{$\begin{array}{c}\text { Radish }^{2} \\
\text { Shoot } \\
\text { wt } \\
(\mathrm{mg})\end{array}$} & \multirow{2}{*}{$\begin{array}{c}\text { Alfalfa }^{y} \\
\text { Shoot } \\
\text { area } \\
\left(\mathrm{cm}^{2}\right)\end{array}$} & \multicolumn{3}{|c|}{ Stevens cranberry $^{x}$} \\
\hline & $\begin{array}{l}\text { Shoot } \\
\text { ht } \\
(\mathrm{cm})\end{array}$ & $\begin{array}{l}\text { Shoot } \\
\text { wt } \\
(\mathrm{mg})\end{array}$ & & & $\begin{array}{l}\text { Shoot } \\
\text { count } \\
\text { (no.) }\end{array}$ & $\begin{array}{c}\text { Shoot } \\
\text { wt } \\
\text { (mg/shoot) }\end{array}$ & $\begin{array}{c}\text { Root } \\
\text { nodes } \\
\text { (no.) }\end{array}$ \\
\hline 0 & 14.9 & 89 & 113 & 3.0 & 1.7 & 83 & 3.5 \\
\hline 11.4 & 12.8 & 81 & 114 & 4.2 & 1.4 & 82 & 3.4 \\
\hline 114 & 18.7 & 124 & 110 & 5.0 & 1.8 & 79 & 4.1 \\
\hline 1140 & 8.4 & 36 & 6 & 0.4 & 1.6 & 9 & 0.4 \\
\hline LSD $^{\mathrm{w}}$ & 4.2 & 34 & 53 & 0.9 & NS & 25 & 0.9 \\
\hline
\end{tabular}

${ }^{2}$ Harvested 16 days after planting (DAP).

${ }^{y}$ Harvested 43 DAP.

${ }^{x}$ Harvested 38 DAP. Root node no. is the total number of nodes on the runners that developed roots.

wean separation within columns at $P \leq 0.05$ by Fisher's protected LSD.

Table 2. The effects of a phytotoxin from Pseudomonas syringae on the growth of corn spurry and fireweed seedlings, and silverleaf, birdsfoot trefoil (Bft), and 'McFarlin' cuttings (weights, fresh basis).

\begin{tabular}{|c|c|c|c|c|c|c|c|c|c|c|c|}
\hline \multirow[b]{2}{*}{$\begin{array}{l}\text { Phytotoxin } \\
\text { (ppm) }\end{array}$} & \multicolumn{2}{|c|}{ Corn spurry $^{z}$} & \multicolumn{2}{|c|}{ Fireweed $^{z}$} & \multicolumn{2}{|c|}{ Silverleaf $^{\mathrm{y}}$} & \multicolumn{2}{|c|}{$\mathrm{Bft}^{\mathrm{y}}$} & \multicolumn{3}{|c|}{ McFarlin cranberry ${ }^{\mathrm{x}}$} \\
\hline & $\begin{array}{l}\text { Shoot } \\
\text { wt } \\
\text { (g) }\end{array}$ & $\begin{array}{l}\text { Root } \\
\text { wt } \\
(\mathrm{mg})\end{array}$ & $\begin{array}{l}\text { Shoot } \\
\text { wt } \\
\text { (g) }\end{array}$ & $\begin{array}{l}\text { Root } \\
\text { wt } \\
(\mathrm{mg})\end{array}$ & $\begin{array}{l}\text { Shoot } \\
\text { wt } \\
(\mathrm{mg})\end{array}$ & $\begin{array}{l}\text { Root } \\
\text { wt } \\
(\mathrm{mg})\end{array}$ & $\begin{array}{c}\text { Shoot } \\
\text { wt } \\
(\mathrm{mg})\end{array}$ & $\begin{array}{l}\text { Root } \\
\text { wt } \\
(\mathrm{mg})\end{array}$ & $\begin{array}{c}\text { Shoot } \\
\text { total } \\
\text { (no.) }\end{array}$ & $\begin{array}{c}\text { Shoot } \\
\text { wt } \\
\text { (mg/shoot) }\end{array}$ & $\begin{array}{l}\text { Root } \\
\text { wt } \\
(\mathrm{mg})\end{array}$ \\
\hline 0 & 2.2 & 320 & 1.2 & 360 & 917 & 730 & 448 & 208 & 2.8 & 115 & 78 \\
\hline 103 & 0.1 & 0 & 0 & 0 & 570 & 450 & 253 & 61 & 2.5 & 86 & 38 \\
\hline 563 & 0 & 0 & 0 & 0 & 416 & 245 & 25 & 0 & 0.2 & 4 & 6 \\
\hline 1030 & 0 & 0 & 0 & 0 & 138 & 3 & 32 & 0 & 0 & 0 & 0 \\
\hline LSD $^{\mathrm{w}}$ & 0.3 & 44 & 0.4 & 66 & 243 & 249 & 204 & 105 & 0.9 & 39 & 25 \\
\hline
\end{tabular}

${ }^{2}$ Harvested 42 days after planting (DAP). The establishment of corn spurry and fireweed seedlings was not affected at $1 \mathrm{ppm}$ and reduced $(P \leq 0.10)$ at $10 \mathrm{ppm}$ phytotoxin.

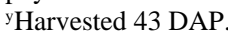

${ }^{x}$ Harvested 67 DAP

${ }^{\text {w} M e a n ~ s e p a r a t i o n ~ w i t h i n ~ c o l u m n s ~ a t ~} P \leq 0.05$ by Fisher's protected LSD. 
2). Consequently, $103 \mathrm{ppm}$ of phytotoxin was a selective dose relative to 'Stevens' cranberries (Table 1). These data indicate that the phytotoxin may have practical use as an annual weed control agent in newly established bogs.

There were no differences in the weights of silverleaf and birdsfoot trefoil cuttings at the time of transplanting (data not shown). Silverleaf root and shoot growth were reduced at all concentrations of phytotoxin, including 103 ppm by 43 DAP (Table 2). Root and shoot weight of birdsfoot trefoil were reduced, respectively, at 103 and $563 \mathrm{ppm}$ phytotoxin. These data indicate that the growth or spread of these perennial weeds may be suppressed at 103 ppm of phytotoxin.

Shoot and root growth of partially rooted 'McFarlin' cranberry vines was inhibited 67 DAP, respectively, at 563 and 103 ppm of phytotoxin (Table 2). At $103 \mathrm{ppm}$, shoot weight was not affected. Some of the tolerance at 103 ppm of phytotoxin may have been attributed to the significantly greater weights of the cuttings at the time of transplanting. 'McFarlin' cranberry vine weights at transplanting were $345,445,346$, and $320 \mathrm{mg}$, respectively, at 0 , 103,563 , and $1030 \mathrm{ppm}$. These data indicate that there may be no selective dose of phytotoxin that can control these annual or perennial weeds without injuring partially rooted 'McFarlin' cranberry vines.

The season of application may affect the response to the phytotoxin. Cranberry tolerance to herbicides diminishes after seasonal growth commences. 'McFarlin' cranberries were treated in midsummer as opposed to the early spring application used for 'Stevens'.
Also, there may be differential sensitivity of 'Stevens' and 'McFarlin' varieties to the phytotoxin. The relative tolerance of cranberries to the phytotoxin compared to both annual and perennial weeds will not be known conclusively until field trials are conducted.

The data presented herein suggest that the phytotoxin in our crude extract of $P$. syringae has potential as a means of annual weed control in newly established 'Stevens' cranberry bogs. Commercial use of the phytotoxin (strain 3366 or other isolates) will require significant developments in the areas of purification, characterization, and formulation chemistry to increase both the activity toward problematic weeds and the margin of safety to cranberries.

\section{Literature Cited}

Bolton, H., Jr., and L.F. Elliott. 1989. Toxin production by a rhizobacterial Pseudomonas sp. that inhibits wheat root growth. Plant \& Soil 114:269 278

Cherrington, C.A. and L.F. Elliott. 1987. Incidence of inhibitory pseudomonads in the Pacific Northwest. Plant \& Soil 101:159-165.

Eck, P. 1990. The American cranberry. Rutgers Univ. Press, New Brunswick, N.J.

Elliott, L.F. and J.M. Lynch. 1984. Pseudomonads as a factor in the growth of winter wheat (Triticum aestivum L.). Soil Biol. Biochem. 16:69-71.

Fredrickson, J.K. and L.F. Elliott. 1985. Effects on winter wheat seedling growth by toxin-promoting rhizobacteria. Plant \& Soil 83:399-409.

Gealy, D.R., S. Gurusiddaiah, A.C. Kennedy, and A.G. Ogg. 1992. Effects of phytotoxins from Pseudomonas fluorescens strain D7 on seed germination and seedling growth of downy brome (Bromus tectorum L.). Abstr. Weed Sci. Soc. Amer. 32:51.
Gurusiddaiah, S., D.R. Gealy, A.C. Kennedy, and A.G. Ogg. 1992. Production, isolation, and characterization of phytotoxic and fungistatic compounds for biocontrol of downy brome (Bromus tectorum $\mathrm{L}$.) and pathogenic fungi. Abstr. Weed Sci. Soc. Amer. 32:84.

Jann, R.C. and R.D. Amen. 1977. What is germination?, p. 7-28. In: A.A. Khan (ed.). The physiology and biochemistry of seed dormancy and germination. North-Holland Publishing Co., Amsterdam.

Kennedy, A.C., L.F. Elliott, F.L. Young, and C.L. Douglas. 1991. Rhizobacteria suppressive to the weed downy brome. Soil Sci. Soc. Amer. J. 55:722-727.

Shanks, C.H. and F. Agudelo-Silva. 1990. Field pathogenicity and persistence of heterohabditid and steinernematid nematodes (Nemotoda) infecting black vine weevil larvae (Coleoptera: Curculionidae) in cranberry bogs. J. Econ. Entomol. 83:107-110.

Suslow, T.V. and M.N. Schroth. 1982. Role of deleterious rhizobacteria as minor pathogens in reducing crop growth. Phytopathology 72:111115.

Swanton, C.J., K.N. Harker, and R.L. Anderson. 1993. Crop losses due to weeds in Canada. Weed Sci. 7:537-542.

Tranel, P.J., D.R. Gealy, and G.P. Irzyk. 1993a. Physiological responses of downy brome (Bromus tectorum) roots to Pseudomonas fluorescens strain D7 phytotoxin. Weed Sci. 41:483-489.

Tranel, P.J., D.R. Gealy, and A.C. Kennedy. 1993b. Inhibition of downy brome (Bromus tectorum) root growth by a phytotoxin from Pseudomonas fluorescens strain D7. Weed Technol. 7:134139.

U.S. Department of Agriculture. 1952. Manual for testing agricultural and vegetable seeds. U.S. Dept. Agr. Agr. Hdbk. 30. U.S. Govt. Printing Office, Washington, D.C. 